\title{
The Role of Internet Development in China's Grain Production: Specific Path and Dialectical Perspective
}

\author{
Xuehao Bi ${ }^{1}$, Bo Wen ${ }^{2} \mathbb{D}$ and Wei Zou ${ }^{1, *}$ \\ 1 College of Public Administration, Nanjing Agricultural University, Nanjing 210095, China; \\ 2020209030@stu.njau.edu.cn \\ 2 College of Landscape Architecture, Nanjing Forestry University, Nanjing 210037, China; \\ wenbo2019@njfu.edu.cn \\ * Correspondence: zw@njau.edu.cn
}

check for updates

Citation: Bi, X.; Wen, B.; Zou, W. The Role of Internet Development in China's Grain Production: Specific Path and Dialectical Perspective. Agriculture 2022, 12, 377 . https://doi.org/10.3390/ agriculture12030377

Academic Editor: Jean-Paul Chavas

Received: 14 January 2022

Accepted: 6 March 2022

Published: 8 March 2022

Publisher's Note: MDPI stays neutral with regard to jurisdictional claims in published maps and institutional affiliations.

Copyright: (C) 2022 by the authors. Licensee MDPI, Basel, Switzerland. This article is an open access article distributed under the terms and conditions of the Creative Commons Attribution (CC BY) license (https:// creativecommons.org/licenses/by/ $4.0 /)$.
Abstract: With the development of the internet in China, information asymmetry in traditional agriculture production has been alleviated, and the information on modern agricultural technologies and production factor mobility has been widely disseminated, significantly impacting the country's grain productivity and output. The pertinence and effectiveness of food security system arrangement can be ensured by revealing the influence of the internet on grain production. Based on the panel data of 30 provincial administrative regions in China from 1997 to 2018, a mediation model and a moderation model were used to evaluate the effect of internet development on grain output and constraints. The results showed that grain output could be promoted as internet penetration directly increases, and can also be boosted by enhancing technology usage and promoting operation scale expansion through the internet. However, the positive effect of this cycle could be inhibited by rural population aging, as there are many barriers faced by the elderly using information and communication technology (ICT). Strengthening agricultural technology utilization and promoting large-scale operation can encourage the development of rural internet, consequently improving the national food security guarantee capacity. It is equally important to simplify internet usage to alleviate the adverse impact of population aging on grain output. This study contributes to three sections of literature on (i) the factors influencing grain output, (ii) the mediating effects of the information transmission function of the internet, (iii) and the potential impact of aging in the information era. Exploring agricultural growth from an innovative perspective of the internet can provide a reference for ensuring food security and agricultural informatization.

Keywords: the internet; grain production; agriculture technology; operation scale; rural aging

\section{Introduction}

Food security is an essential guarantee for world peace and development, which is always the prioritization in state governance in China. In 2019, the population in China had exceeded 1.4 billion, and it is likely that the growth curve will keep going up. With the population and dietary consumption of livestock products increasing, China's food demand, especially grain demand, will continue to surge in the future [1]. Hence, the country needs to invest and guarantee a constantly improving production mode to ensure grain output security.

In developing countries, inadequate information dissemination is considered a major factor hindering the improvement of the agricultural production mode [2]. For a long time, information and communication technologies (ICTs) developed slowly in rural areas, so farmers were limited by little access to agricultural information. Under such circumstances, technology acquisition and factor input are restricted, and the circulation of production factors is also hindered. As modern information technology has boomed in the last 20 years and become widespread in urban and rural areas in China, more people can access any 
kind of information using the internet, a phenomenon that relieved inadequate information dissemination. For instance, when the COVID-19 pandemic broke out in 2020, many rural areas of China shut down most commerce and transport, and productivity was threatened by restrictions on the mobility of production factors, including labor [3]. Nevertheless, an internet-based production mode was formed through the online guidance of agricultural experts and the online sales of inputs. Consequently, the grain output of 2020 in many areas of China did not decrease compared with previous years [4]. The effectiveness of information technologies proves that the internet can be used as a supporting tool in food production.

The positive effect of the internet in agriculture has garnered boundless concerns. These effects have been studied from multiple aspects, i.e., the promotion of agricultural product sales [5], facilitation of financing for agrarian operators [6], and innovation of agricultural services [7]. In contrast to the wide recognition of the benefits of the internet, very few studies have observed the impacts of information dissemination on grain production input and output.

Theoretical research and empirical evidence show that information dissemination has always had a significant effect on farmer learning and decision-making [8]. Multiple studies demonstrate this correlation. For instance, effective information transmission was found to be a strong determinant of modern agricultural technologies during the adoption and diffusion process $[9,10]$. Furthermore, research has evidenced that few approaches of information transmission e.g., village cadre imparting agricultural techniques, would result in information monopoly causing misunderstanding among the farming community [11]. The internet is the most popular platform for information exchange and could be used to expand farmers' information acquisition channels, avoiding the inefficiency of a few stand approaches and enhancing marketization. Besides, if the internet is used to drive the flow of production factors, this could make the factor allocation structure more reasonable at the macro level, conducive to the grain yield. While the role of the internet in grain production has already proved to be significant, the effect of the internet on grain output and the limiting conditions in the process are still unclear.

As a carrier of information transmission, the internet affects the input and output of grain production by acting on the intermediaries, including technology, labor, and land. As a developing country, China's agricultural society is constantly transforming, and many conveniences for agricultural development are brought by information modernization. However, the populational aging issue is hindering this development [12]. In this context, the improvement of information modernization in agricultural development could be proposed based on the effects of internet development on China's farm production and the analysis of the restriction factors. This study presents an analytical framework for the impact of internet development on grain production. First, the direct and indirect effects of the internet were discussed to fully evaluate its effectiveness in agricultural development. Then, a detailed explanation of the relationship between the internet, grain production, and the constraint from rural aging is presented. Furthermore, an empirical test was carried out with provincial panel data to better understand the promotion of agricultural information in China, the digital divide faced by the elderly, and the risks of using the internet in these circumstances. The research results can provide a reference for relevant departments to make specific policy arrangements that rely on the positive role of Internet information technology to ensure food security.

\section{Literature Review and Theoretical Analysis}

\subsection{Literature Review}

As the next phase of agriculture development for sustaining the continuously increasing population [13], modern Agriculture 4.0 is a hot spot of academic research. After the previous revolutions-Agriculture 1.0 witnessed the hunter-gatherers turn to settled agriculture, Agriculture 2.0 saw the innovation of agricultural machines, Agriculture 3.0 involved the Green Revolution, affecting the production in developing countries—-the fourth 
is coming [14]. Agriculture 4.0, which is also called digital agriculture and smart agriculture, is simply defined as the combination between precision agriculture and ICT [15]. The concept of Agriculture 4.0 involves the extension of the definition of precision agriculture, emphasizing the production process, not only through the acquisition of relevant data and processing but also through the optimization of decision-making functions, through intelligent technology and ICT to improve agricultural processes, improve efficiency and decision-making ability, and increase food security [16,17]. As one of the main characteristics of smart agriculture is the implementation of modern ICT on farms by farmers who seek for increasing the productivity of agriproducts [18], the internet is an indispensable part of modern agriculture. Therefore, under the background of Agriculture 4.0 development, exploring the mechanism of the internet is of great significance to ensure food security and agricultural modernization. Agricultural modernization is an inevitable trend. It has been put forward that future studies should consider ways to involve farmers and developing countries in the fourth agricultural revolution and address technical issues in Agriculture 4.0 [19].

The existing literature has thoroughly discussed the development process, conception, characteristics, significance, and future trend of Agriculture 4.0. It provides a theoretical and literature basis for this study to explore the effect of the Internet on agricultural production and grain output. The influence of the internet has various specific paths, and its effectiveness is conditional. However, these are often overlooked. The following section is a theoretical analysis of the role of the internet from direct and indirect perspectives, and the restraint factor of internet participation promoting Agriculture 4.0.

\subsection{Direct and Indirect Effect of the Internet}

Over the past decades in China, agriculture has transformed from traditional to modern practice, and has positively impacted the effective deployment of ICTs [20]. Under these circumstances, the integration of informatization and agricultural modernization became a powerful means to increase farm yield and efficiency [21]. As an important component of ICT, the internet is the basis of informatization and can be a platform for information dissemination, which would help reduce farmers' search costs and facilitate the effective acquisition of grain production information [22]. Internet-based technology is a significant part of Agriculture 4.0, which addresses the agricultural production challenge in food security [23] and is being widely used in the agricultural field. The Internet of Things, for instance, could send customized management messages based on a specific location, soil type, and management records, so farmers can detect the state of crop growth on time. In this case, farmers would take the standardized measure of irrigation, fertilizers, seeds, and other farm inputs accordingly, leading to improved yields with a lower input cost, labor, and environmental pollution.

Additionally, the internet would indirectly affect grain output through agricultural technology promotion and operation scale expansion.

Research has been accruing to prove the positive effect of agricultural technology on grain yield [24], and smooth information dissemination can also be conducive to technology adoption. The effects of Internet technology on agriculture could be worked from several channels. Firstly, farmers' learning costs could be potentially reduced as agricultural technology knowledge is disseminated by the internet [22]. With the popularization of portable mobile terminals, people can browse technical information on the internet anytime and anywhere [10]. Farmers can follow the opinion of experts online, and two-way interact with each other easily, creating an exchange channel not only for technical knowledge but to obtain feedback that can be used to improve effectiveness of different applications [25]. Compared with the previous experts' point-to-point method of technological guidance, the online method is low-budget and flexible and allows farmer to customize the technology information according to their needs.

Secondly, the internet can also strengthen farmers' social networks by getting them close to constructing interpersonal social communication media. In general, farmers make 
their decisions based on the way people around them use technology, which is also known as the demonstration effect [26]. Online social media reduces communication costs and can help farmers maintain their existing relationships, develop and strengthen the network of 'strong bonds', and create a new channel of communication with strangers, and establish the network of 'weak bonds'. Furthermore, the expansion of social networks can enhance the technological exchange and the uptake of modern technology as well [27].

The improvement of grain output depends not only on the agricultural technology application, but also on the input structure optimization of traditional production factors. For a long time, the agricultural involution of China, coursed by labor over input, hindered the improvement of grain output [28]. However, nowadays, with the popularization of the internet, agricultural surplus labor is promoted to transfer to the non-agricultural sector, increasing the demand for farmland rent out. More precisely, internet development has stimulated many emerging industries, e.g., E-commerce and Uber, which boost the number of jobs available and has the potential to change the traditional employment pattern of migrant workers [29]. Additionally, the internet serves as a medium for the communication of employment information between employers and job seekers, raising the matching efficiency between labor and work. As a result, the frictional unemployment caused by information asymmetry could weaken [30]. On the other hand, the internet provides the farmland demanders with land rent trading information, conducive to the circulation and market allocation of land factors. As a result, agricultural land resources can be concentrated with the farmers with stronger comparative advantages, and their grain planting scale is gradually expanded in this context. In short, the internet optimizes the land-labor ratio and promotes large-scale grain production through the transfer of surplus labor and integrated farmland.

\subsection{Restraining Effect of the Aging}

China has been facing issues with its growing aging population in recent years, especially in rural areas [31]. Until 2019, the proportion of old-aged people (over 65 years old) has accounted for $14.69 \%$ in rural China [32]. Excessive population aging weakens the country's family economic development capacity. Further, at the macro level, it is reflected in the decline of regional agricultural production capacity, which hinders the development of the agrarian economy. Although the positive effects of the internet have been illustrated in terms of direct and indirect impacts mentioned above, considering the reality of rural China, the aging problem would hamper the internet from playing a positive role.

Elderly people face obstacles when using the internet to receive and disseminate information [33]. Due to the different cognitive levels and knowledge backgrounds aligned with the decline of physiological functions, these people have to overcome more interaction barriers when using the internet than younger users [12]. Elderly people have formed their information communication inertia based on years of experience and habits. The internet has only risen in the past few decades, made little contribution to these habits, and has not been widely applied among this age group. For them, the internet is more like a means of entertainment than a channel of production and communication. Even if they still use the internet to some extent, the insufficiency in information collection, acceptance, knowledge acquisition, and application [34] also affects the efficiency of this process. Similar to the aging of the agricultural labor force, the aging of the rural population has a restraining effect on promoting grain output using the internet. The analytical framework illustrated in Figure 1 describes the relationship between the internet, grain output, and constraint. 


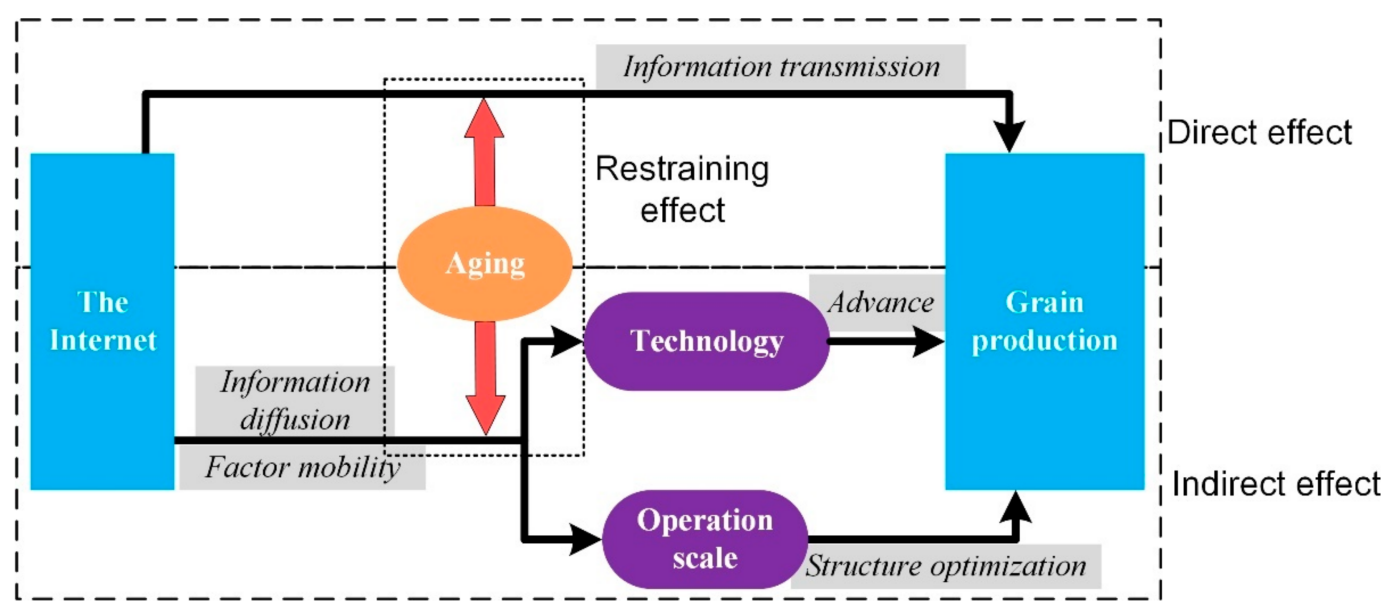

Figure 1. Analytical framework.

\section{Data and Method}

\subsection{Data and Variables}

The internet was late adopted in China. Until 1996, traditional media, including newspapers, radio, television, and news agencies, began to build their websites, and portal websites progressively appeared in China [35]. Since then, the internet has gradually spread among the people and has surpassed other channels to become the most popular information communication platform [36]. Considering the history of the internet, this study regarded data from 30 provinces in China from 1997 to 2018 as samples excluding Tibet, Hong Kong, Taiwan, and Macao. The data on internet penetration was collected from the China Statistical Yearbook of the Tertiary Industry (1998-2019). All the other data were collected from statistical materials such as China Statistical Yearbook (1998-2019), China Rural Statistical Yearbook (1998-2019), China Population \& Employment Statistics Yearbook (1998-2019).

Dependent variable: Grain output per unit area. The grain output is an intuitive representation of grain production capacity. This variable intuitively shows the output situation and is measured in kilograms per hectare. According to the description of grain output in the yearbook, the grains cover cereals, legumes, and potatoes, among which cereals include rice and wheat corn, beans mean soybeans, and potatoes include sweet potatoes and potatoes.

Independent variable: Internet penetration. This variable is a direct reflection of internet usage in a region. Considering devices are required for internet access, the variable will be replaced by other variables, like the number of computers, phones, or both per 100 rural households, in the subsequent robustness test.

Mediator: According to the analysis above, technology application and operation scale are taken as mediators of the relationship between the internet and grain output. An appropriate way to measure technology application is to take a specific technology as an example. The labor-saving technology represented by agricultural machinery plays an essential role in improving the efficiency of the planting industry, especially the grain planting industry [37]. Agricultural mechanization is also the key performance of agricultural modernization. The ratio of total mechanical power to labor has been previously used in studies that examined the mechanical technology situation [38]. Drawing on the above practices, The total power of agricultural machinery per unit labor is used to represent technology application in this study. For the operation scale, this variable is the macroscopic change in the traditional production factor input ratio, which can be represented by Farmland per unit labor. 
Moderator: Aging. Relative rural aging is used to characterize this variable. In this study, aging is centralized, namely, the measurement method of the variable is set as follows:

$$
\text { aging }=p_{i t}-\frac{1}{2018-1996} \sum_{t=1997}^{2018} p_{i t}
$$

where $p$ is the proportion of the rural aging population (over 65-years-old), $i$ is the $i$ th province, $t$ is the year.

Control variables: Control variables are other variables that affect grain output, including disaster condition, irrigation condition, fertilizer consumption, agricultural investment, and education.

The variables and their meanings are shown in Table 1.

Table 1. Variables and descriptive statistics.

\begin{tabular}{|c|c|c|c|c|c|c|}
\hline Type & Variables & Meaning & Mean & Std. Dev. & Min & Max \\
\hline $\begin{array}{l}\text { Dependent } \\
\text { variable }\end{array}$ & Grain & Grain output per unit area $(\mathrm{kg} / \mathrm{ha})$ & 4895.135 & 1062.036 & 2405.556 & 7983.063 \\
\hline $\begin{array}{l}\text { Independent } \\
\text { variable }\end{array}$ & Internet & Internet penetration (\%) & 24.860 & 22.300 & 0.000 & 78.000 \\
\hline \multirow[t]{2}{*}{ Mediator } & Technology & $\begin{array}{l}\text { Total power of agricultural machinery } \\
\text { per unit labor }(\mathrm{kW} / \text { person })\end{array}$ & 5.613 & 3.651 & 0.524 & 19.829 \\
\hline & Scale & Farmland per unit labor(ha/person) & 0.473 & 0.358 & 0.013 & 2.119 \\
\hline \multirow[t]{2}{*}{ Moderator } & Aging & Relative rural aging $(\%)$ & 0.000 & 3.068 & -5.430 & 12.098 \\
\hline & Disaster & The proportion of disaster areas (\%) & 26.150 & 17.170 & 0.000 & 93.083 \\
\hline \multirow{4}{*}{$\begin{array}{l}\text { Control } \\
\text { variable }\end{array}$} & Irrigated & $\begin{array}{l}\text { The proportion of effective irrigated } \\
\text { farmland }(\%)\end{array}$ & 39.950 & 16.180 & 13.910 & 100.000 \\
\hline & Fertilizer & $\begin{array}{l}\text { Fertilizer consumption per unit area } \\
\qquad(\mathrm{kg} / \mathrm{ha})\end{array}$ & 333.901 & 125.954 & 120.790 & 778.945 \\
\hline & Investment & $\begin{array}{l}\text { Agricultural investment per unit area } \\
\qquad(10,000 \text { yuan/ha })\end{array}$ & 0.128 & 0.133 & 0.002 & 1.709 \\
\hline & Illiterate & $\begin{array}{c}\text { The proportion of illiterates in rural } \\
\text { areas (\%) }\end{array}$ & 12.300 & 7.390 & 2.700 & 57.620 \\
\hline
\end{tabular}

Before proceeding with the estimation, it should be checked whether potential multicollinearity problems might impact the estimation results. The correlation between explanatory variables is shown in Table 2, and the highest one is 0.629 . According to previous research [39], if the correlation is below 0.85 , it means that the multicollinearity is not a serious issue in estimation.

Table 2. Correlation matrix.

\begin{tabular}{|c|c|c|c|c|c|c|c|c|c|}
\hline & Internet & Technology & Scale & Disaster & Irrigated & Fertilizer & Investment & Illiterate & Aging \\
\hline Internet & 1 & & & & & & & & \\
\hline Technology & 0.500 & 1 & & & & & & & \\
\hline Scale & 0.145 & 0.414 & 1 & & & & & & \\
\hline Disaster & -0.491 & -0.209 & 0.135 & 1 & & & & & \\
\hline Irrigated & 0.373 & 0.523 & 0.164 & -0.250 & 1 & & & & \\
\hline Fertilizer & 0.508 & 0.270 & -0.282 & -0.339 & 0.418 & 1 & & & \\
\hline Investment & 0.325 & 0.399 & 0.040 & -0.166 & 0.318 & 0.303 & 1 & & \\
\hline Illiterate & -0.558 & -0.453 & -0.241 & 0.275 & -0.267 & -0.445 & -0.273 & 1 & \\
\hline Aging & 0.629 & 0.268 & -0.154 & -0.477 & 0.123 & 0.372 & 0.137 & -0.378 & 1 \\
\hline
\end{tabular}

\subsection{Econometric Model}

According to the theoretical analysis, the internet has both a direct effect on grain output and an indirect effect with technology application and operation scale as mediators. The method proposed by the previous study [40] can be used to build the mediation model to test these effects. The stepwise regression method proposed by Wen et al. [41] is used to test the mediating effect. The mediation model can be expressed with formulas (2) to (4):

$$
\begin{gathered}
\text { Grain }_{i t}=a_{0}+a_{1} \text { Internet }_{i t}+\sum a_{j} X_{j i t}+\mu_{i}+\lambda_{t}+\varepsilon_{i t} \\
M_{i t}=\beta_{0}+\beta_{1} \text { Internet }_{i t}+\sum \beta_{j} X_{j i t}+\mu_{i}+\lambda_{t}+\varepsilon_{i t}
\end{gathered}
$$




$$
\text { Grain }_{i t}=\gamma_{0}+\gamma_{1} \text { Internet }_{i t}+\gamma_{2} M_{i t}+\sum \gamma_{j} X_{j i t}+\mu_{i}+\lambda_{t}+\varepsilon_{i t}
$$

where $i$ and $t$ represent provinces and years, respectively, $i=1,2, \ldots \ldots 30$, and $t=1997$, 1998, . . . . . 2018; Grain represents grain output; Internet represents internet penetration; $M$ represents mediator including technology and operation scale; $X$ represents control variables; $\mu_{i}$ is unobserved province individual effect; $\lambda_{t}$ is unobserved time effect, while $\varepsilon_{i t}$ is the random error term.

The following moderating effect model is constructed to investigate the constraint mechanism of aging on the influence of the internet on grain output. The model can be expressed as formula (5):

$$
\text { Grain }_{i t}=a_{0}+a_{1} \text { Internet }_{i t}+a_{2} \text { Internet }_{i t} \times \text { aging }_{i t}+a_{3} \text { aging }_{i t}+\sum a_{j} Z_{j i t}+\mu_{i}+\lambda_{t}+\varepsilon_{i t}
$$

where $a_{\text {ging }}$ it represents relative rural aging in the $t$ year of the $i$ province; Internet $_{\text {it }} \times \operatorname{aging}_{\text {it }}$ is the interaction term between the internet and rural aging, $Z$ represents control variables, while the other variables in formula (5) have the same meanings as formula (2) to (4).

\section{Results}

\subsection{Direct and Indirect Effect of the Internet on Grain Output}

The estimation result of the mediation model is presented in Table 3. As panel data are used, the Hausman test is first carried out on the models. The test values are all significant at the $10 \%$ level, indicating that the Hausman tests rejected the random effect model (RE), thereby adopting a fixed effect model (FE) to the analysis can be considered reasonable. To avoid heteroscedasticity and autocorrelation, Driscoll-Kraay standard errors are used to estimate models.

\begin{tabular}{|c|c|c|c|c|c|c|}
\hline $\begin{array}{c}\text { Dependent } \\
\text { Variable }\end{array}$ & Grain & Technology & Scale & Grain & Grain & Grain \\
\hline & Model 1 & Model 2 & Model 3 & Model 4 & Model 5 & Model 6 \\
\hline Internet & $\begin{array}{l}9.925 * * * \\
(2.075)\end{array}$ & $\begin{array}{l}0.049 * * * \\
(0.007)\end{array}$ & $\begin{array}{l}0.035^{* * *} \\
(0.004)\end{array}$ & $\begin{array}{l}8.418^{* * *} \\
(2.646)\end{array}$ & $\begin{array}{l}7.189 * * * \\
(1.999)\end{array}$ & $\begin{array}{l}6.927 * * * \\
(2.341)\end{array}$ \\
\hline Technology & & & & $\begin{array}{l}30.691 * * \\
(14.056)\end{array}$ & & $\begin{array}{c}13.364 \\
(17.753)\end{array}$ \\
\hline Scale & & & & & $\begin{array}{c}77.852 \text { *** } \\
(15.605)\end{array}$ & $\begin{array}{l}66.635 * * * \\
(21.317)\end{array}$ \\
\hline Disaster & $\begin{array}{c}-12.046^{* * *} \\
(1.350)\end{array}$ & $\begin{array}{c}-0.015^{* * *} \\
(0.005)\end{array}$ & $\begin{array}{c}-0.013^{* * *} \\
(0.004)\end{array}$ & $\begin{array}{c}-11.573 * * * \\
(1.203)\end{array}$ & $\begin{array}{c}-11.039 * * * \\
(1.380)\end{array}$ & $\begin{array}{c}-10.978^{* * *} \\
(1.313)\end{array}$ \\
\hline Irrigated & $\begin{array}{l}1.194 \\
(2.534)\end{array}$ & $\begin{array}{c}-0.044^{* *} \\
(0.018)\end{array}$ & $\begin{array}{c}0.007 \\
(0.007)\end{array}$ & $\begin{array}{l}2.540 \\
(2.595)\end{array}$ & $\begin{array}{c}0.665 \\
(2.618)\end{array}$ & $\begin{array}{l}1.327 \\
(2.417)\end{array}$ \\
\hline Fertilizer & $\begin{array}{l}0.596^{*} \\
(0.296)\end{array}$ & $\begin{array}{l}-0.001 \\
(0.002)\end{array}$ & $\begin{array}{c}-0.005^{* * *} \\
(0.001)\end{array}$ & $\begin{array}{l}0.624^{* *} \\
(0.293)\end{array}$ & $\begin{array}{c}0.951 * * * \\
(0.318)\end{array}$ & $\begin{array}{l}0.912^{* * *} \\
(0.300)\end{array}$ \\
\hline Investment & $\begin{array}{l}-147.880 \\
(107.364)\end{array}$ & $\begin{array}{c}1.583 \\
(1.795)\end{array}$ & $\begin{array}{l}-0.033 \\
(0.546)\end{array}$ & $\begin{array}{c}-196.471^{* *} \\
(77.856)\end{array}$ & $\begin{array}{c}-145.322 \\
(86.043)\end{array}$ & $\begin{array}{c}-166.849 * * \\
(76.820)\end{array}$ \\
\hline Illiterate & $\begin{array}{l}-8.253 \\
(5.036)\end{array}$ & $\begin{array}{c}-0.131 \text { *** } \\
(0.017)\end{array}$ & $\begin{array}{c}0.005 \\
(0.012)\end{array}$ & $\begin{array}{l}-4.228 \\
(3.757)\end{array}$ & $\begin{array}{c}-8.661 \text { * } \\
(4.340)\end{array}$ & $\begin{array}{c}-6.849^{* *} \\
(3.131)\end{array}$ \\
\hline Constant & $\begin{array}{c}4837.546^{* * *} \\
(180.255)\end{array}$ & $\begin{array}{c}8.259 * * * \\
(0.758)\end{array}$ & $\begin{array}{c}5.383^{* * *} \\
(0.263)\end{array}$ & $\begin{array}{c}4584.053^{* * * *} \\
(173.179)\end{array}$ & $\begin{array}{c}4418.467^{* * * *} \\
(221.674)\end{array}$ & $\begin{array}{c}4368.469 * * * \\
(204.130)\end{array}$ \\
\hline Hausman & $12.840^{* *}$ & $32.120^{* * *}$ & 30.760 *** & 12.860 * & 16.540 ** & 15.580 ** \\
\hline
\end{tabular}

Table 3. The result of the mediation model.

Note: ${ }^{*}{ }^{* *}$ and ${ }^{* * *}$ indicate significant at the $10 \%, 5 \%$ and $1 \%$ level, respectively; Drisc/Kraay Standard errors are in parentheses.

As is shown in Model 1, the total effect of the internet is significantly positive, suggesting that the widespread use of the internet stimulates the main cereal grain yield in China, which is consistent with the outcomes of Sylvester O et al.'s study in Kenya [2]. 
The total effect can be decomposed into direct and mediating effects, i.e., the indirect effect previously mentioned in Section 2.1. Based on Model 1, the mediating variables, Technology, and Scale were added to Model 6 as explanatory variables, so the coefficient of the internet was the direct effect that is 6.927 with a positive impact at the significance level of $1 \%$. The result showed that every $1 \%$ increase in internet penetration would increase grain output by $6.927 \mathrm{~kg}$ per hectare. As one kind of ICTs, the internet transmits information between people, and also between people and things (Internet of Things). Therefore, the application helps farmers to time-efficiently manage operations, save costs, improve accuracy, and reducing possible production losses [42].

The coefficient of the internet was considered significant in all models, and the coefficient of Technology and Scale was also significant in Models 4 and 5. This proves that the mediating effect actually exists, according to the mediating effect test procedure proposed by Wen Zhonglin, et al. [41]. Comparing Model 1 with Model 6, the effect of the internet changed from 9.925 to 6.927 , demonstrating that the two mediators explained $30 \%$ of the comprehensive impact of internet development on grain output.

Model 2 shows that the internet promotes agricultural technology application at the significance level of $1 \%$. This is mainly because the internet improves the transmission efficiency of technology information, reduces information asymmetry, and diffuses the resulting feedback of technology utilization, demonstrating to those who do not usually access it. Model 4 shows that the internet coefficient decreases after controlling the technology variable. It also shows part of the promoting effect of the internet is occupied by Technology; that is, agricultural technology application is a path in which the internet affects grain output.

The results of Model 3 show that the coefficient of the internet is significantly positive, indicating that it increases grain operation scale and optimizes the factor input ratio. This is because the rapid development of the internet and information technology makes management and information exchange more convenient and also accelerates the circulation of production factors, especially labor and land. This promotes agricultural surplus labor transferring to cities and adjusts land allocation, significantly increasing the average operation scale. Similarly, Model 5 also indicates that operation scale expansion is an indirect path of the impact of the internet on grain production.

From the results of control variables (Model 6), it can be concluded that: (1) Disaster has a significant negative impact on grain output, indicating that the effect of natural disasters on grain yield cannot be ignored. (2) Increasing chemical fertilizer input can significantly promote grain yield. The high input of chemical fertilizers and pesticides has been the main reason for grain production enhancement in recent years, but this input caused non-point source pollution and unsustainable land use [43]. At present, the Chinese government is actively encouraging the use of organic fertilizer and formula fertilization by soil testing instead of high chemical fertilizer input [44,45]. (3) The agricultural investment contains all the investment on both grain and other crops. Generally, cash crops need more investment, and the grain output is low in areas where cash crops are widely grown, which can explain why the coefficient is negative. (4) The coefficient of Illiteracy is significantly negative, which suggests that the current grain production relies on simple labor input and also requires farmers have certain human capital to help them learn and apply new technology to promote the grain output increase.

\subsection{Restraining Effect of Aging between the Internet and Grain Output}

The estimation result of the moderating effect model is presented in Table 4. According to the results of the Hausman test, FE is adopted to analyze the data. Driscoll-Kraay standard errors are also used. In Model 1, the Aging coefficient is significantly positive, matching the result from a previous study [46]. The elderly labor strength decline and the lack of local labor factors may be the main reasons behind this phenomenon. Local farmers tend to adopt mechanized operations and other labor-substitution technologies for land cultivation. Furthermore, the elderly rent the farmland which they have no spare energy to 
cultivate to others, therefore the land resources are more concentrated and the scale effect is easy to be formed in grain production. The inhibitory effect of the interaction between internet and Aging on Grain shown in Model 1 indicates that rural aging limits the positive impact of internet penetration on grain yield.

Table 4. Result of moderating effect model.

\begin{tabular}{ccccc}
\hline $\begin{array}{c}\text { Dependent } \\
\text { Variable }\end{array}$ & Grain & Technology & Scale & Grain \\
& Model 1 & Model 2 & Model 3 & Model 4 \\
\hline Internet & $8.046^{* * *}(1.489)$ & $0.035^{* * *}(0.009)$ & $0.026^{* * *}(0.004)$ & $6.200^{* * *}(1.981)$ \\
Aging & $56.686^{* * *}(12.931)$ & $0.505^{* * *}(0.065)$ & $0.291^{* * *}(0.036)$ & $35.1633^{* *}(13.612)$ \\
Internet $\times$ aging & $-0.582^{* *}(0.259)$ & $-0.006^{* * *}(0.001)$ & $-0.003^{* *}(0.001)$ & $-0.348(0.239)$ \\
Technology & & & $9.162(18.345)$ \\
Scale & & & Controlled & Controlled \\
Control variables & Controlled & Controlled & $4442.228^{* * *}$ \\
Constant & $4824.194^{* * *}$ & $8.087^{* * *}(0.747)$ & $5.300^{* * *}(0.249)$ & $(201.457)$ \\
Hausman & $(173.186)$ & $34.420 * * *$ & $50.600 * *$ & 21.160 ** \\
Observations & $17.060^{* *}$ & 660 & 660 & 660 \\
\hline
\end{tabular}

Note: ${ }^{*}{ }^{* *}$ and ${ }^{* * *}$ indicate significance at the $10 \%, 5 \%$, and $1 \%$ level, respectively; Drisc/Kraay Standard errors are in parentheses.

The moderating effect of Aging on mediating variables can be observed in Model 2 and Model 3. The regression coefficients of the interaction term were significantly negative in both models, suggesting that the more severe the aging degree, the weaker the promoting effect of the internet on Technology and Scale. The reason for the above results may be that the internet as a communication and information transmission platform, promotes the technology transfer and factors market circulation, while the effect depends on the internet users' operational ability and information acceptance. At present, internet service and related equipment operations are more suitable to young and middle-aged people, and there is a lack of elderly user-friendly internet products. As a result, the information absorption of the elderly population is not synchronized with internet development, which is reflected in the negative moderating effect of Aging at the macro level. It should be noted that in Model 4, the $p$-value of the interaction term between internet and Aging is 0.160 . After the restriction of the significance level is moderately relaxed, the effect of internet $x$ aging interaction is still significant. In other words, the effect of the interaction term is positive at the significance level of $16 \%$.

\subsection{Endogenous Treatment and Robustness Test}

\subsubsection{Endogenous Treatment}

In the process of the internet promoting grain output, endogeneity may occur due to the reverse causality between the dependent variable and independent variable. Specifically, farmers seek adequate information through various methods while pursuing the increase of grain yield, which will promote the development of information transmission channels and accelerate internet popularization. The instrumental variable (IV) method, with a two-stage least square (2SLS) used for estimation can be used to solve the endogeneity problem caused by the reverse causality. Selecting the first lag of the internet (Internet_1) as IV can avoid the influence of grain output on the internet in time, which conforms to the exogenous condition of IV. Moreover, internet use is a kind of communication consumption behavior, and the rachet effect shows that once consumption behavior is formed, it is unlikely to change in a short period. Therefore, Internet_1 also meets the endogenous condition of IV.

2SLS estimated Models 1 and 2 represented in Table 5. The result of the Hausman test significantly rejects Hypothesis 0 that the internet is exogenous, indicating that the internet is indeed an endogenous variable. The internet variable (Model 1) is first estimated with the instrumental variable Internet_1 as the explanatory variable, and the predicted value of the internet is obtained. Then, the predicted value replaced the endogenous variable internet 
into the original model for estimation (Model 2). As it can be seen from Model 2, after the modification of endogeneity, the influence of the internet on grain is still significantly positive, which again confirms the benchmark regression result.

Table 5. Result of endogenous treatment and robustness test.

\begin{tabular}{|c|c|c|c|c|c|}
\hline \multirow[b]{2}{*}{$\begin{array}{c}\text { Dependent } \\
\text { Variable }\end{array}$} & \multicolumn{2}{|c|}{ Endogenous Treatment } & \multicolumn{3}{|c|}{ Robustness Test } \\
\hline & Internet & Grain & Grain & Grain & Grain \\
\hline & Model 1 & Model 2 & Model 3 & Model 4 & Model 5 \\
\hline Internet & & $7.393^{* * *}(1.252)$ & & & \\
\hline Internet_1 & $0.988^{* * *}(0.008)$ & & & & \\
\hline Computer & & & $10.330 * * *(1.589)$ & & \\
\hline Phone & & & & $1.851^{* * *}(0.284)$ & \\
\hline Device & & & & & $1.718^{* * *}(0.251)$ \\
\hline Control variables & Controlled & Controlled & Controlled & Controlled & Controlled \\
\hline Constant & $2.978^{* * *}(0.780)$ & $4326.726(205.583)$ & $\begin{array}{c}4461.319^{* * * *} \\
(202.555)\end{array}$ & $\begin{array}{c}4265.346^{* * *} \\
(200.278)\end{array}$ & $\begin{array}{c}4298.941^{* * * *} \\
(199.732)\end{array}$ \\
\hline Observations & 630 & 630 & 660 & 660 & 660 \\
\hline
\end{tabular}

Note: ${ }^{*}, * *$ and ${ }^{* * *}$ indicate significant at the $10 \%, 5 \%$ and $1 \%$ level, respectively; Standard errors are in parentheses.

\subsubsection{Robustness Test}

This study adopts the method of replacing the variable indicators to estimate again as a means to verify the robustness of the estimation results presented in Table 3 . Since using the internet requires holding devices, the key independent variable internet is replaced with other variables, including the number of computers, phones, or both per 100 rural households. The results shown in Table 5 indicate that the coefficients of each variable are significantly positive, representing the robustness of baseline regression results.

\section{Discussion}

\subsection{Government-Led and Market-Led Agricultural Information Sources Promote Grain Production}

Agricultural informatization is one of the keys to achieve agricultural modernization [13]. Agricultural information, a specific term used in China, refers to the process of widely using information technologies in agricultural production and management, including both the process of transforming information technology into productive forces and the industrialization process of agricultural information production and service [47]. This study focuses on the role of the internet as an ICT in the latter process.

Agricultural information dissemination service is one of the key contents to implementing agricultural informatization strategy. The modes and efficiency of agricultural information dissemination from different agricultural information sources are completely different. At present, the two main modes of agricultural information dissemination in China are government-led and market-led. The government-led extension mode is also the traditional model that has been popular for a long time in China. Its operation mode is top-down and consistent with China's 5-level vertical administrative management system. The guidance is first formulated by the Ministry of Agriculture (central), and then the information is conveyed through the extension centers of provincial, city-level, and county-level agricultural departments, and finally implemented in rural agricultural technology extension stations. Due to the low efficiency and limitation of vertical extension management, this traditional model not only covers a limited number of farmers [48], failing to meet farmers' demands for immediate, accurate, and convenient personalized information [49].

In terms of Market-led modes, there are various information extension services, among which the internet is one of the most popular in the digital age. The effect of the internet on grain output includes the direct impact of information transmission and the indirect impact of technology application and operation scale expansion. Among them, the formation of the indirect mechanism also benefits from the information expansion service of the 
internet. The portal website is a vital part of information service and could push a variety of product information to farmers, including agricultural news, policies, agricultural market, technology education, training, and production factors flow information. For example, China's Rural Distance Education Network (http://www.ngx.net.cn/ accessed on 12 January 2022) provides a myriad of online courses and agricultural technology guidance videos. Disclosing production factor trading information through network platforms is the current trend. "TULIU NET" (website for land transfer, https://www.tuliu.com/ accessed on 12 January 2022) is a platform where users can post information about on-sale farmland use rights or find land available for rent. In addition to web portals, WeChat public accounts and agricultural information extension apps are also useful internet tools for agrarians $[10,20]$. In general, the internet has great potential in promoting grain and agricultural production, which is worthy of in-depth exploration by the government and social organizations.

\subsection{Age-Friendly Internet Development Would Help Alleviate the Restraining Effect on Grain Production by Rural Population Aging}

The results presented in this study illustrate that rural aging weakens the promoting effect of internet popularity on grain production, in which the poor internet usage by older people plays a pivotal role. The old-aged person is usually at a disadvantage when using the internet, a phenomenon described as the "digital divide" [50]. Substantial research revealed the barriers of the elderly participant in digital engagement, and it was demonstrated that low-income people who cannot afford high internet fees lack awareness about the benefits of the internet. Physical and psychological impairments, and cognitive decline in later life were the most common reasons behind this mismatch [51-54].

Moreover, considering the limited opportunities for accessing the internet and digital information technology in rural areas, it is suitable to say that the rural aging population use less of this technology than the elderly urban population [55]. Even old people are subjectively willing to make a digital engagement. A case study involving a rural community in South Australia [56] has shown that older people felt responsible for improving their internet skills and would like to participate in online services. However, because of long-held beliefs about older people's lack of interest or ability to use information technology, older people's willingness to engage with the internet is often underestimated by service and app providers. When designing programs, they tend to ignore the digital participation needs of the elderly and are even unwilling to change their digital service strategies to adapt to the habits of the elderly and other special groups.

For rural China, online agricultural production services must consider the needs and habits of the elderly, which would help narrow the digital divide. In recent years, with the rapid development of China's secondary and tertiary industries, young and middle-aged rural labor force continues to migrate to cities, causing aging pressure on agricultural and rural production. By 2010, China had 2.23 million agricultural laborers over the age of 65 . The employment rate of males and females over 65 in rural areas is $61.99 \%$ and $38.0 \%$, indicating that the elderly labor force cannot be ignored [12]. While strengthening the construction of communication technology infrastructure, an age-friendly concept is best incorporated into developers' service strategies, eliminating interaction barriers and making information systems more accessible [33]. The government should also encourage software developers to recognize and address the usage and cognitive difficulties that specific users, i.e., the elderly, may face. Rural communities can organize training and guidance for older adults to overcome the issues caused by the digital divide.

\subsection{Adverse Rumors from the Internet on Grain Production Need to Be Filtrated}

Despite the positive effect of the internet on grain production, the usage process still has risks. According to the analysis presented here, the internet promotes grain production via the widespread dissemination of product information. Still, this process is assertive only if the information being transmitted is accurate and true. 
However, information on the internet is often challenging to distinguish between true and false. Compared with traditional media, the internet is more likely to allow rumors to emerge unexpectedly and spread quickly [57]. Traditional media, e.g., newspapers, radio, television stations, etc., are sponsored mainly by authoritative organizations, and the content is often released in a one-to-many instance, so the information disclosed is highly reliable. On the other hand, the open nature of web platforms determines that every ordinary individual has the unprecedented right to publish and disseminate content, so the cost of information publishing and dissemination is very low or even zero. In the internet era, the information transmission mode is generally based on a many-to-many relationship, making the rumor transmission more complex and diversified. In agricultural production, rumors may mislead farmers' judgment on technology application and market to a certain extent, which is harmful to grain production.

To avoid the interference of internet rumors on grain information, the farming community's informational cycle should be strengthened from two aspects. First, it is important to promote the production and access to high-quality agricultural information, and experts in the field need to be encouraged to communicate online with farmers and offer reliable recommendations. Furthermore, farmers must be taught means to strengthen their ability to discriminate information. Rumors can be updated quickly, so it is necessary to organize regular rumor-denying education in communities to help farmers, especially elderly users who are easily gullible, improve their rumor-screening capacity.

\section{Conclusions}

The present study investigated the effects of internet development on the main cereal grain output in 30 provinces of the People's Republic of China. A mediation model was employed to analyze the different mechanisms by which the internet affects output, both directly and indirectly. A moderating effect model was then employed to examine the moderating effect of rural aging on internet use. Finally, the possible issue of endogeneity and robustness were dealt with and tested. The research findings emphasize the significance of the internet on grain production in the information era, and also support policies to promote active usage of the internet among farmers. The econometric results indicate that: (1) internet development can improve grain production output, (2) agricultural technology application and operation scale expansion are two specific paths for the internet to promote output, and (3) rural aging has an inhibitory effect on the internet promoting grain production.

Based on the above conclusions, the following policy implications can be drawn. (1) The ICT-related infrastructure and the construction of internet infrastructure in rural areas need to be invested in promote internet applications. (2) An effective online factor flow information platform should be established to enhance the marketization function of internet allocation factors, further popularizing modern agricultural technology and promoting farmland transfer and intensive large-scale land operation. (3) Software companies should be encouraged to innovate internet applications and develop network systems suitable for the elderly to make up for their objectivity difficulties when surfing the internet.

The limitations of this study should also be acknowledged. The analysis presented here only focuses on grain production, and the findings should be applied to other crops with caution, since the production mode and factor input structure of grain is different from other crops. In the light of these findings, future work could concentrate on the effects of differences in internet usage on technology input, factor input and grain production behavior, and explore how to eliminate the "digital divide" issue faced by elderly farmers.

Author Contributions: Conceptualization, X.B. and W.Z.; methodology, B.W.; software, X.B.; formal analysis, X.B., W.Z., B.W.; data curation, X.B.; writing-original draft preparation, X.B.; writing-review and editing, B.W., W.Z.; supervision, W.Z.; project administration, W.Z.; funding acquisition, W.Z. All authors have read and agreed to the published version of the manuscript.

Funding: This research was supported by The National Natural Science Foundation of China (42071221). 


\section{Institutional Review Board Statement: Not applicable.}

Informed Consent Statement: Not applicable.

Data Availability Statement: Not applicable.

Conflicts of Interest: The authors declare no conflict of interest.

\section{References}

1. Wei, X.; Zhang, Z.; Wang, P.; Tao, F. Recent patterns of production for the main cereal grains: Implications for food security in China. Reg. Environ. Chang. 2016, 17, 105-116. [CrossRef]

2. Ogutu, S.O.; Okello, J.J.; Otieno, D.J. Impact of Information and Communication Technology-Based Market Information Services on Smallholder Farm Input Use and Productivity: The Case of Kenya. World Dev. 2014, 64, 311-321. [CrossRef]

3. Shirsath, P.B.; Jat, M.L.; McDonald, A.J.; Srivastava, A.K.; Craufurd, P.; Rana, D.S.; Singh, A.K.; Chaudhari, S.K.; Sharma, P.C.; Singh, R.; et al. Agricultural labor, COVID-19, and potential implications for food security and air quality in the breadbasket of India. Agric. Syst. 2020, 185, 102954.

4. Yin, C. Food Development and Food Security in Post Epidemic Era. Issues Agric. Econ. 2021, 1, 4-13.

5. Du, Y. Network Poverty Alleviation and E-commerce into Rural Areas in the Context of Rural Vitalization Strategy. Truth Seek. 2019, 3, 97-108.

6. Zhou, Y.; Da, Y.; Yu, Y. Analysis on the Creative Mode of 'Internet + Agricultural Industry Chain' Finance: An Example of Nxin Pig Industry Chain. Issues Agric. Econ. 2020, 1, 78-81.

7. Guo, H. The Internet Drives the Innovation of Agricultural Producer Services: Based on the Value Chain Perspective. Rural. Econ. 2019, 1, 125-131.

8. Skaalsveen, K.; Ingram, J.; Urquhart, J. The role of farmers' social networks in the implementation of no-till farming practices. Agric. Syst. 2020, 181, 102824. [CrossRef]

9. Genius, M.; Koundouri, P.; Nauges, C.; Tzouvelekas, V. Information Transmission in Irrigation Technology Adoption and Diffusion: Social Learning, Extension Services, and Spatial Effects. Am. J. Agric. Econ. 2014, 96, 328-344. [CrossRef]

10. Gao, Y.; Zhao, D.; Yu, L.; Yang, H. Influence of a new agricultural technology extension mode on farmers' technology adoption behavior in China. J. Rural Stud. 2020, 76, 173-183. [CrossRef]

11. Zhang, J.; Zhang, J.; Wu, F. Economic analysis of high intensity application of pesticides in grain production in China. Theory Pract. Financ. Econ. 2018, 39, 140-146.

12. Liao, L.; Long, H.; Gao, X.; Ma, E. Effects of land use transitions and rural aging on agricultural production in China's farming area: A perspective from changing labor employing quantity in the planting industry. Land Use Policy 2019, 88, 104152. [CrossRef]

13. Meghna, R.; Shashank, G.; Vinay, C.; Anubhav, E.; Tanya, G.; Mohammed, A.; Dusit, N. A survey on the role of Internet of Things for adopting and promoting Agriculture 4.0. J. Netw. Comput. Appl. 2021, 187, 103107.

14. Rose, D.C.; Morris, C.; Lobley, M.; Winter, M. Exploring the spatialities of technological and user re-scripting: The case of decision support tools in UK agriculture. Geoforum 2018, 89, 11-18. [CrossRef]

15. Daniel, A.; Rodrigo, L.P.; José, C.F.J.; Jenyffer, S.G.S.; Rafaela, P.M. Agriculture 4.0: A terminological introduction. Rev. Cienc. Agron. 2020, 51, e20207737.

16. Shen, S.; Basist, A.; Howard, A. Structure of a digital agriculture system and agricultural risks due to climate changes. Agric. Agric. Sci. Procedia 2010, 1, 42-51. [CrossRef]

17. Lioutas, E.D.; Charatsari, C. Land Use Policy Smart Farming and Short Food Supply Chains: Are They Compatible? Land Use Policy 2020, 94, 104541. [CrossRef]

18. Mistry, I.; Tanwar, S.; Tyagi, S.; Kumar, N. Blockchain for 5G-enabled IoT for industrial automation: A systematic review, solutions, and challenges. Mech. Syst. Signal Process. 2020, 135, 106382. [CrossRef]

19. Silveira, F.D.; Lermen, F.H.; Amaral, F.G. An overview of agriculture 4.0 development: Systematic review of descriptions, technologies, barriers, advantages, and disadvantages. Comput. Electron. Agric. 2021, 189, 106405. [CrossRef]

20. Zhang, Y.; Wang, L.; Duan, Y. Agricultural information dissemination using ICTs: A review and analysis of information dissemination models in China. Inf. Process. Agric. 2016, 3, 17-29. [CrossRef]

21. Rabiya, A.; Pablo, M.; Rafiq, A. The digitization of agricultural industry-A systematic literature review on agriculture 4.0. Smart Agric. Technol. 2022, 2, 100042.

22. Tack, J.; Aker, J.C. Information, Mobile Telephony, and Traders' Search Behavior in Niger. Am. J. Agric. Econ. 2014, 96, 1439-1454. [CrossRef]

23. Gebbers, R.; Adamchuk, V.I. Precision Agriculture and Food Security. Science 2010, 327, 828-831. [CrossRef] [PubMed]

24. Yang, Y.; Lin, W.; Zhang, L. Agricultural technological progress, technical efficiency and food production: An empirical analysis from provincial panel data in China. J. Agrotech. Econ. 2017, 5, 46-56.

25. Yao, Z.; Ding, T. Preliminary study on the informatization construction of basic level agricultural technology extension in Changyuan county. Prim. Agric. Technol. Ext. 2018, 6, 5-6.

26. Case, A.C. Neighborhood influence and technological change. Reg. Sci. Urban Econ. 1992, 22, 491-508. [CrossRef] 
27. Wood, B.A.; Blair, H.T.; Gray, D.I.; Kemp, P.D.; Kenyon, P.R.; Morris, S.T.; Sewell, A.M. Agricultural Science in the Wild: A Social Network Analysis of Farmer Knowledge Exchange. PLoS ONE 2014, 9, e105203. [CrossRef]

28. Myers, R.H.; Huang, P.C.C. The Peasant Economy and Social Change in North China. Am. Hist. Rev. 1985, 90, 1253. [CrossRef]

29. Liu, H. From 'Social Mines' to 'Social Factory' -Study on the 'Center-scatter' structure in the Era of digital capitalism. Economist 2020, 5, 36-45.

30. Dettling, L.J. Broadband in the labor market: The impact of residential high speed internet on married women's labor force participation. Financ. Econ. Discuss. Ser. 2013, 70, 451-482. [CrossRef]

31. Fan, L.; Dang, X.; Tong, Y.; Li, R. Functions, motives and barriers of homestead vegetable production in rural areas in ageing China. J. Rural Stud. 2019, 67, 12-24. [CrossRef]

32. China DoPaESNBoSo. China Population E Employment Statistics Yearbook 2020; China Statistics Press: Beijing, China, 2020.

33. Gregor, P.; Dickinson, A. Cognitive difficulties and access to information systems: An interaction design perspective. Univers. Access Inf. Soc. 2007, 5, 393-400. [CrossRef]

34. Tauer, L. Age and Farmer Productivity. Rev. Agric. Econ. 1995, 17, 63-69. [CrossRef]

35. Liu, L. History of the development of Internet journalism in China. Internet Econ. 2016, 7, 90-97.

36. Fang, X.; Zhong, X. The development course, rule and enlightenment of Chinese portal websites. News Writ. 2019, 2, 5-10.

37. Yang, J.; Huang, Z.; Zhang, X.; Reardon, T. The Rapid Rise of Cross-Regional Agricultural Mechanization Services in China. Am. J. Agric. Econ. 2013, 95, 1245-1251. [CrossRef]

38. Deng, X.; Zhang, K.; Qi, Y. Does cultural differences hinder agricultural technology diffusion? Evidence from rural dialect distance and agricultural mechanization. China Econ. Stud. 2019, 6, 58-71.

39. Lee, G. The effectiveness of international knowledge spillover channels. Eur. Econ. Rev. 2006, 50, 2075-2088. [CrossRef]

40. Baron, R.M.; Kenny, D.A. The moderator-mediator variable distinction in social psychological research: Conceptual, strategic, and statistical considerations. Chapman Hall 1986, 51, 1173-1182. [CrossRef]

41. Wen, Z.; Zhang, L.; Hou, J.; Liu, H. Testing and application of the mediating effects. Acta Psychol. Sin. 2004, 36, 614-620.

42. Verdouw, C.; Tekinerdogan, B.; Beulens, A.; Wolfert, S. Digital twins in smart farming. Agric. Syst. 2021, 189, 103046. [CrossRef]

43. Zhou, S.; Su, S.; Meng, L.; Liu, X.; Zhang, H.; Bi, X. Potentially toxic trace element pollution in long-term fertilized agricultural soils in China: A meta-analysis. Sci. Total Environ. 2021, 789, 147967. [CrossRef]

44. Li, B.; Shen, Y. Effects of land transfer quality on the application of organic fertilizer by large-scale farmers in China. Land Use Policy 2021, 100, 105124. [CrossRef]

45. Liu, Y.; Ruiz-Menjivar, J.; Zhang, L.; Zhang, J.; Swisher, M.E. Technical training and rice farmers' adoption of low-carbon management practices: The case of soil testing and formulated fertilization technologies in Hubei, China. J. Clean. Prod. 2019, 226, 454-462. [CrossRef]

46. Li, J.; Feng, Z.; Wu, Q. The Aging Effect of Agriculture Labor Force on Grain Production in China-An Empirical Study Based on the Labor-Augmenting Production Function. J. Agrotech. Econ. 2018, 8, $26-34$.

47. Liu, C. Sustainability of rural informatization programs in developing countries: A case study of China's Sichuan province. Telecommun. Policy 2016, 40, 714-724. [CrossRef]

48. Tong, D.; Wu, H.; Ying, R. The Impacts of Grassroots Public Agricultural Technology Extension on Farmers' Technology Adoption: An Empirical Analysis of Rice Technology Demonstration. China Rural. Surv. 2018, 4, 59-73.

49. Bavorová, M.; Unay-Gailhard, İ.; Ponkina, E.V.; Pilařová, T. How sources of agriculture information shape the adoption of reduced tillage practices? J. Rural. Stud. 2020, 79, 88-101. [CrossRef]

50. Townsend, L.; Sathiaseelan, A.; Fairhurst, G.; Wallace, C. Enhanced broadband access as a solution to the social and economic problems of the rural digital divide. Local Econ. J. Local Econ. Policy Unit 2013, 28, 580-595. [CrossRef]

51. Barnard, Y.; Bradley, M.D.; Hodgson, F.; Lloyd, A.D. Learning to use new technologies by older adults: Perceived difficulties, experimentation behaviour and usability. Comput. Hum. Behav. 2013, 29, 1715-1724. [CrossRef]

52. Carpenter, B.D.; Buday, S. Computer use among older adults in a naturally occurring retirement community. Comput. Hum. Behav. 2007, 23, 3012-3024. [CrossRef]

53. Gell, N.M.; Rosenberg, D.E.; Demiris, G.; Lacroix, A.Z.; Patel, K.V. Patterns of Technology Use among Older Adults with and without Disabilities. Gerontologist 2013, 55, 412-421. [CrossRef]

54. Yu, D.; Fiebig, D.G. Internet use and cognition among middle-aged and older adults in China: A cross-lagged panel analysis. J. Econ. Ageing 2020, 17, 100262. [CrossRef]

55. Berner, J.; Rennemark, M.; Anderberg, P.; Sköldunger, A.; Wahlberg, M.; Elmståhl, S.; Berglund, J. Factors influencing Internet usage in older adults (65 years and above) living in rural and urban Sweden. Health Inform. J. 2014, 21, 237-249. [CrossRef]

56. Hodge, H.; Carson, D.; Carson, D.; Newman, L.; Garrett, J. Using Internet technologies in rural communities to access services: The views of older people and service providers. J. Rural Stud. 2017, 54, 469-478. [CrossRef]

57. Nguyen, T.T.; Nguyen, T.T.; Nguyen, T.T.; Vo, B.; Jo, J.; Nguyen, Q.V.H. JUDO: Just-in-time rumour detection in streaming social platforms. Inf. Sci. 2021, 570, 70-93. [CrossRef] 